\title{
Quantitative relationship of spore and plant assemblages from the Radnice Basin, Middle Pennsylvanian of the Czech Republic: preliminary results
}

\author{
Jiří BEK ${ }^{1, *}$, Stanislav OPLUŠTIL ${ }^{2}$, Josef PŠENIČKA ${ }^{3}$ and Jana VOTOČKOVÁ-FROJDOVÁ ${ }^{1}$ \\ 1 Academy of Sciences of the Czech Republic, Institute of Geology v.v.i., Rozvojová 269, 16500 Prague 6, Czech Republic \\ 2 Charles University, Faculty of Sciences, Albertov 2038, 12800 Prague 2, Czech Republic \\ 3 Centre of Palaeobiodiversity, West Bohemian Museum, Kopeckého sady 357/2, 30100 Plzeň, Czech Republic
}

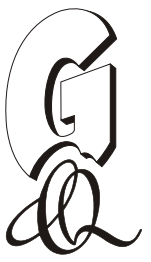

Bek, J., Opluštil, S., Pšenička, J., Votočková-Frojdová, J., 2021. Quantitative relationship of spore and plant assemblages from the Radnice Basin, Middle Pennsylvanian of the Czech Republic: preliminary results. Geological Quarterly, 65: 59, doi: 10.7306/gq. 1628

Associate Editor: Michał Zatoń

Dispersed miospore and pollen assemblages are described from the Radnice Basin, Middle Pennsylvanian, Czech Republic. Conversion factors (R-values) were produced by comparing the palynological data with quantified macrofloral data, to relate the percentages of spore/pollen taxa to those of the major plant groups that produced them. Among arborescent lycopsids, the miospore and macroplant counts are more or less equal. In other lycopsids miospores are strongly over-represented, as their macroplant remains were relatively fewer than would be suggested by the proportion of their spores in miospore spectra. Sphenophyll and calamitid macroplants were also relatively fewer than are their spores as a proportion of palynological spectra. By contrast, macroplants of ferns and cordaites are relatively more numerous than are their miospores and pollen in palynological spectra.

Key words: Pennsylvanian, spores, fossil plants.

\section{INTRODUCTION}

The dispersed miospore and pollen record is driven by the dispersal strategy of their parent plant producers, and these microfossils are many times more numerous than plant macrofossils. Spores and pollen have much higher fossilisation potential than plant macrofossils because of their successful dispersal strategy, due to often enormous production in reproductive organs except for pteridosperm pollen that are preserved rarely. Advantage of spores are: (1) repeated reproduction, (2) small spore size, (3) suitable morphology for wide aerial and secondary aquatic dispersal including pollen sacs and (4) resistant exine consisting of sporopollenin that protected spores and pollen during dispersal while equally being highly resistant to degradation over geological timescales.

All these characteristics explain why the diversity of palynomorphs in a particular bed greatly exceeds that of the macroflora (Bek and Opluštil, 2021), and so palynological data better reflect the original diversity of vegetation colonising the landscape (Capel et al., 2021). In addition, most fossil plants

\footnotetext{
* Corresponding author, e-mail: mrbean@gli.cas.cz
}

Received: September 28, 2021; accepted: November 21, 2021; first published online: December 27, 2021 are found as allochthonous fragments classified under different generic and specific names assigned to particular organs (bark, branches, foliage, roots, reproductive organs, etc.), and so there is commonly uncertainty about which organs belong to which natural plant species (e.g., Bateman and Hilton, 2009; Wang et al., 2009, 2021a). This further complicates the estimation of original plant diversity from the macrofloral record even at a generic level, as well as the estimation of relative proportions of taxa, i.e., the size of their populations. By contrast, spores and pollen are found as complete specimens, and the counting of dispersed miospore and pollen species/genera on a slide is a common approach to providing quantified palynological data. Unfortunately, the percentage of miospore/ pollen taxa is, for various reasons, not directly "transformable" into the relative abundance of the parent plants in a former vegetation cover. Besides the taphonomical bias related to the different dispersal strategies of various miospore taxa, there are other reasons why the percentage of spore and pollen taxa cannot be directly related to the relative abundance of the parent plants. These reasons include differences in production of miospores by various parent plants and the production of more than one miospore species by some plant taxa. The former is demonstrated by systematic underrepresentation of pollen of medullosalean affinity in palynological spectra, while in compression or coal ball records their macrofloral remains are usually more common and or even dominant and taxonomically diverse (Willard, 1993; Willard and Phillips, 1993; Bek and 
Opluštil, 2021). Similarly, the predominance of small monolete marattialean miospores over cordaitalean pollen of Florinites type in dispersed assemblages does not necessarily reflects the same ratio of abundances of their parent plants in the original vegetation. The latter bias is well documented by spores of Omphalophloios, a sub-arborescent lycopsid which in sporangia of a single plant may bear two miospore genera (Densosporites and Cristatisporites) including several species (Bek and Opluštil, 1998; Bek et al., 2014) thus resulting in inflation of miospore diversity compared to that of the plants.

To overcome this bias, various conversion parameters have been developed. This approach was introduced by Davis (1963) for quantitative characterization of recent pollen. In the fossil record, the first attempt at quantitative comparison of fossil plant and spore records was published by Willard (1993) and Willard and Phillips (1993) who used R-values/conversion factors. Willard (1993) and Willard and Phillips (1993) counted the area (square $\mathrm{mm} / \mathrm{cm}$ ) of each plant from peel sections of coal-balls and compared this with the percentage of their dispersed miospores/pollen from the same coal-ball. The "coal-ball" conversion factor was defined as a ratio of percentages of spores or pollen species to the percentage of aerial biomass of its parent plant species in the coal-ball record.

$$
\mathrm{R}=\frac{\text { spore species abudance }[\%]}{\text { plant species aerial biovolume }[\%]}
$$

Willard (1993) and Willard and Phillips (1993) stated that spores of arborescent lycopsids and ferns are slightly over-represented, sphenopsids about three times over-represented and ferns four times over-represented. The results of Willard (1993) and Willard and Phillips (1993), including the typical variations of errors, are seen on their Table 1.

Besides coal balls, another opportunity to compare palynological and macrofloral records in terms of the composition and abundance of the original plant groups in the vegetation is provided by localities with autochthonous flora. The best examples are localities where flora was buried in situ by volcanic ash fall, which preserves the structure and composition of vegetation cover in a geological instant (Burnham and Spicer, 1986; Burnham, 1994). The best studied localities of this type are of Middle Pennsylvanian (late Duckmantian) age in the western part of the Czech Republic (Libertín and Bek, 2004; Šimůnek et al., 2009; Opluštil et al., 2009, 2014; Pšenička and Opluštil, 2013; Libertín et al., 2014) and an early Permian tuff bed in the Wuda coalfield, China (Wang et al., 2012a, b; Opluštil et al., 2021; Zhou et al., 2021).

Fossil forests are preserved in tuff beds usually $40-70 \mathrm{~cm}$ thick overlying the coal. The flora in these tuff beds is buried in situ and represents the peat-forming vegetation (Pfefferkorn and Wang, 2007; Opluštil et al., 2007). Excavation of the tuff beds at these localities provided unique data on the structure of these tropical peat swamp forests (see Opluštil et al., 2014, 2021 for an overview).

At one of these localities, at Ovčín in the Radnice Basin, the vegetation cover was reconstructed in spectacular detail (Opluštil et al., 2009, 2014). In addition, a few millimetres-thick coal layer (in the form of dust) from the contact with the overlying tuff bed was sampled (using a preparation needle) in several places for palynological study to compare macrofloral and palynological records in terms of their composition and the abundance of particular plant groups. Very preliminary results in the form of "adpression" R-values were published by Opluštil et al. (2009b). This paper provides new comparisons of quantified macrofloral and palynological data to refine the correlation of both types of records. For that reason we count "adpression" $\mathrm{R}$-values and compare them with coal-ball values as introduced by Willard (1986) and Willard and Phillips (1986).

\section{GEOLOGICAL BACKGROUND}

Our research is centred to the Radnice Basin, a small erosional remnant of a much larger cluster of continental and formerly interconnected Late Paleozoic basins in the central and western part of the Czech Republic (Fig. 1). Deposition in these basins started in the early Moscovian (late Duckmantian) and lasted until the early Permian (Fig. 2). In the Radnice Basin, however, only the oldest strata represented by the Radnice Member and lower part of the overlying Nýrany Member are preserved due to post-Permian erosion (Pešek et al., 2001; Opluštil et al., 2016). The target of our study is the Radnice Member, the deposition of which took place on an uneven surface of the pre-Carboniferous (Neo-Proterozoic and Cambrian) basement with a topography of several tens of metres. Topographic lows were fluvial valleys incised by rivers into the basement and later filled by sediments of the Radnice Member (Opluštil, 2005). Therefore, the distribution and thickness of the member varies strongly. Intercalated within the dominantly fluvial strata of the Radnice Member are three coal groups. However, in the Radnice Basin only the Radnice group is developed. It consists of the Lower Radnice and Upper Radnice coals separated by the 1 to $>10$-metres-thick Whetstone Horizon (Fig. 2) composed of in situ deposited and redeposited volcaniclastics (Orlov, 1942; Opluštil et al., 2014; Tomek et al., 2021). The stratigraphic position of the Lower and Upper Radnice coals is late Duckmantian (Opluštil et al., 2016). The Lower Radnice Coal is between a few tens of centimetres to $\sim 4 \mathrm{~m}$ thick and consists of a high-ash coal commonly with clastic partings indicating its origin from a planar rheotrophic peat swamp. The more important Upper Radnice Coal is of greater extent, thickness (up to $14 \mathrm{~m}$ ) and of better quality and was heavily exploited in both deep and opencast mines since the end of the 18th century. Coal mining activity ceased following closure of the last opencast mine Pokrok (or "Ovčín") near

Ta ble 1

Permineralized R-values of the Middle and Upper Pennsylvanian of the Illinois Basin (Willard, 1993; Willard and Phillips, 1993) and compression R-values from the Radnice Basin

\begin{tabular}{|l|c|c|c|}
\hline \multirow{2}{*}{ Main plant groups } & \multicolumn{2}{|c|}{ Illinois Basin } & Radnice Basin \\
\cline { 2 - 4 } & R-values (Willard, 1993) & R-values (Willard and Phillips, 1993) & $\begin{array}{c}\text { R-values } \\
\text { (herein) }\end{array}$ \\
\hline Arborescent lycopsids & $0.83(1.09) 1.95$ & - & $0.8(0.8) 0.9$ \\
\hline Ferns & $2.58(3.8) 6.3$ & $0.8(7.9) 32.3-$ & $0.5(0.6) 0.7$ \\
\hline Sphenopsids & $1.18(3.1) 6.56$ & $1.1(2.5) 6.4$ & $1.8(7.3) 23.3$ \\
\hline Cordaites & - & $0.03(1.5) 4.5)$ & $0.2(0.25) 0.3$ \\
\hline
\end{tabular}




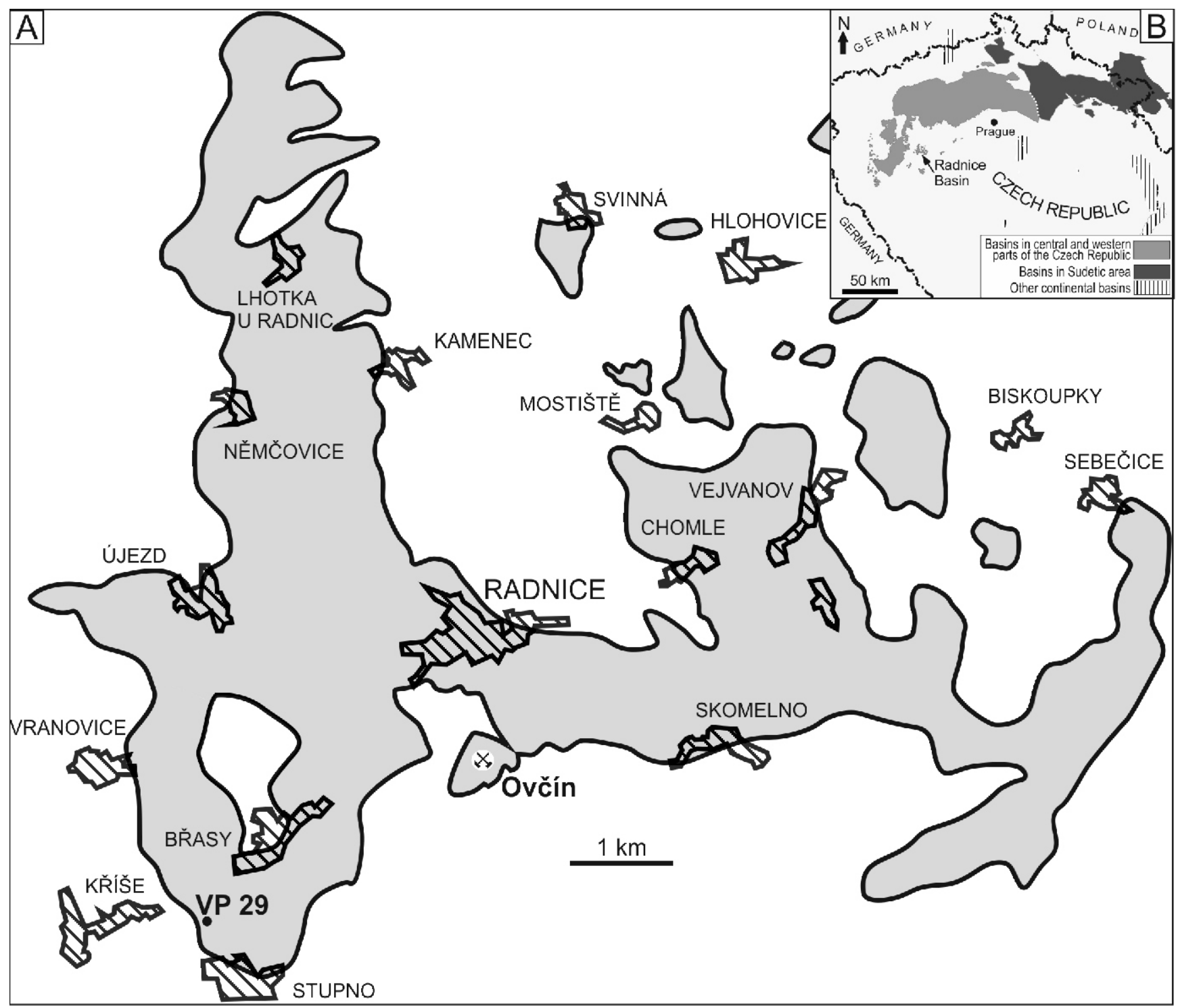

Fig. 1. Map of the Radnice Basin and surrounding relics of Carboniferous strata (A) in the context of other Late Paleozoic basins of the Czech Republic (B)

The positions of the Ovčín opencast mine and borehole VP 29 are indicated

Radnice in 1985. This exploited both coals over an area of about ten hectares.

The Radnice Basin is important historically not only for the exploitation of coal but also for its stratigraphic and especially palaeobotanical research. Some important plant holotypes come from this basin (Sternberg, 1820-1838) and several studies have been published by Czech palaeobotanists and palynologists in last two decades (Opluštil et al., 2009, 2014 Šimůnek et al., 2009; Pšenička and Opluštil, 2013; Libertín and Bek, 2004). Miospore research has been carried out by Bek (1986) and Drábková (1986) and on megaspores by KalibováKaiserová (1959).

\section{GENESIS OF THE WHETSTONE HORIZON}

The Whetstone Horizon includes the fossil record from which the "adpression" R-values in this paper are based. For more details of its origin and plant taphonomy, the reader is re- ferred to Němejc (1930), Opluštil et al. $(2009,2014)$ and Tomek et al. (2021).

The Whetstone Horizon divides the Radnice group of coals into the Lower and Upper Radnice coals and is preserved everywhere the coal group is developed in the coalfields of the western and central Czech Republic. It consists of basal bed of whitish kaolinised acid tuff of sand grain size with a kaolinitic matrix and a thickness of 0.4-0.6 m, persistent over a distance of nearly a hundred kilometres. The bed is called the "Bělka" by miners and is interpreted as in situ volcanic ash fall deposits that may be locally reworked in its uppermost part. Overlying the Berlka is the „Whetstone“ (or "brousek" in Czech), a metre to $>10-m$-thick succession of laminated and ripple-bedded grey mudstones containing volcanic material, the content of which decreases up the section. The Whetstone was formed from unconsolidated tephra washed from the hilly topography down the valleys and deposited in a shallow lake formed by compaction of the peat of the Lower Radnice swamp under the initial volcanic ash load (Opluštil et al., 2014). In the lake, coarser 


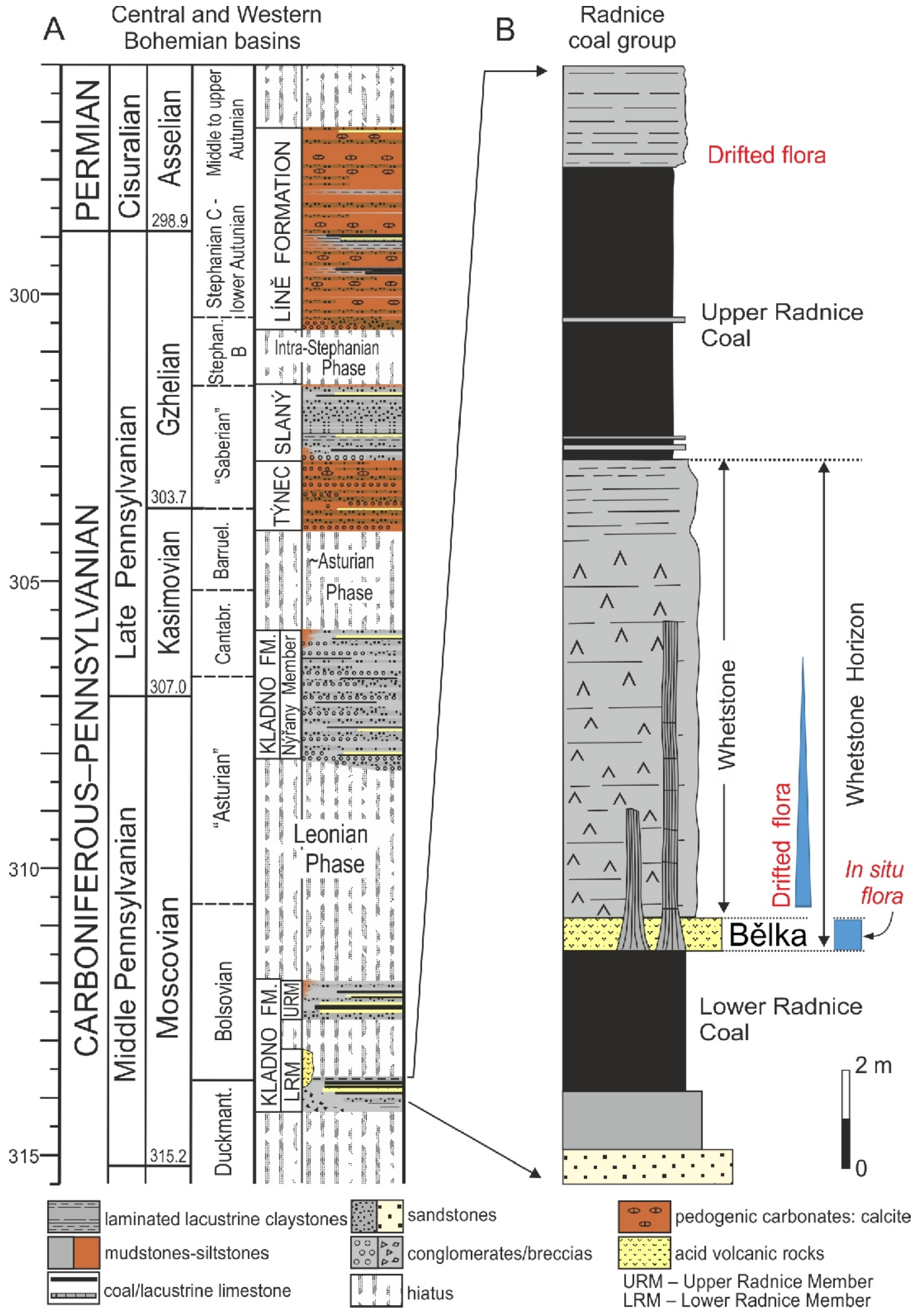

Fig. 2. Lithostratigraphic subdivision of the Permo-Carboniferous basins in the central and western part of the Czech Republic (A) and detailed section of the Radnice coal group with the Whetstone Horizon (B)

The taphonomic character of the fossil record in different parts of the Whetstone Horizon is indicated 
sand-size particles were deposited separately in marginal parts of the lake whereas finer volcaniclastic material settled from suspension in the more distal parts.

The fossil content of the Bèlka and Whetstone differs significantly. That of the Bělka commonly contains large plant fragments (branches, stems, fronds) accompanied by upright stems of various diameters ranging from several millimetres to nearly a metre. Many of them exceed the thickness of the Bělka and continue to the overlying Whestone. In the Ovčín opencast mine the torsa of stems up to $6 \mathrm{~m}$ tall were reported (Opluštil et al., 2014). All the stems are rooted exclusively in the roof of the Lower Radnice Coal. The branches of trees concentrated in the Berlka around the parent stems suggest that trees were damaged by the volcanic ash load with broken branches falling down around the stem. Herbaceous plants are often preserved near the base of the Belka bed suggesting rapid burial in early phases of the volcanic ash fall. As a whole, the vegetation is buried in situ in growth position and allowed reconstruction of the composition and structure of the peat-forming forest (Opluštil et al., 2009, 2014), and improved whole-plant reconstruction of many plant species including their spores/pollen (e.g., Drábková et al., 2004; Libertín and Bek, 2004; Šimůnek et al., 2009; Pšenička and Schultka, 2009; Opluštil, 2010) and their life strategies including epiphytes (Pšenička and Opluštil, 2013). In contrast, the Whetstone includes only drifted and fragmented identifiable plant remains or plant detritus, the former found often as isolated remains, the latter concentrated in bedding planes or millimetre to centimetre-thick sandy laminae within the Whetstone. These features clearly indicate the allochthonous origin of plant fossils preserved in the Whetstone.

\section{MATERIAL AND METHODS}

Between 2002 and 2009, peat-swamp vegetation of the Lower Radnice Coal preserved in the Bělka bed was uncovered and documented in six excavations over a total area of $\sim 200 \mathrm{~m}^{2}$. All plant fossils found in excavations were localised within quadrants and subsequently used for reconstruction of the former forest in great detail including the density and composition of the groundcover, the number of trees, and whether they were dead or alive (Opluštil et al., 2009, 2014). In the excavations made in 2002 several coal samples were taken from the roof of the Lower Radnice Coal at the direct contact with the Bělka (Fig. 3) for palynology and further comparison with the macrofloral record. From the first set of fifteen samples only three of them from square units B3, D2 and D4 have so far yielded miospores and pollen. For comparison a sample was used one from the uppermost part of the Lower Radnice Seam in the VP-29 borehole (14.5-15.0 m) $\sim 3 \mathrm{~km}$ from the excavation (Fig. 1A).

Conversion factors were counted by comparison of the quantified palynological and macrofloral data, i.e., we used the same principle established by Willard (1993) and Willard and Phillips (1993) on coal-ball material. Palynological data were expressed as the percentage abundance of spore/pollen taxa assigned to particular major plant groups based on number of the specimens. To make the data on palynomorph abundances directly comparable with the abundance of parent plant species assigned to the same plant groups in the excavated original peat-forming forest, we quantified the macrofloral data. We delimited circles of 3 and $4 \mathrm{~m}$ in diameter around each palynological sample and counted how many square metres were occupied by plant remains of particular plant groups in the circle. The "compression" R-values for the plant groups were than calculated as a ratio between the percentage of palynomorphs of each particular plant group and the percentage cover of macrofossils of its corresponding plant group within the circles of both sizes. This meant that we counted what percentage one major parent plant group comprises (based on square centimetres) in a circle.

Descriptive terms for the spores follow the latest edition of the Glossary of Pollen and Spore Terminology (Punt et al., 2007). Spores are classified according to the system of dispersed spores suggested by Potonié and Kremp $(1954,1955)$ and Smith and Butterworth (1967). In situ spores were compared directly with the original diagnoses (type specimens), descriptions, and illustrations of dispersed spore species. Species determinations are based only on the original diagnoses, and not on the interpretations of subsequent authors. Macerations of the spores were done in the Institute of Geology v.v.i., Academy of Sciences of the Czech Republic, Prague, Czech Republic) by one co-author (J.B.). Spores were recovered by dissolving small portions of sporangia with the aid of nitric acid $\left(\mathrm{HNO}_{3}\right.$, $60 \%)$ for $24-40$ hours and in potassium hydroxide $(\mathrm{KOH}, 10 \%)$ for 20 minutes.

\section{RESULTS}

\section{D2 SAMPLE}

Punctatisporites obesus is the most abundant miospore species. Alatisporites pustulatus also occurs, an important indicator for this stratigraphical level and area (Bek, 1986; Drábková, 1986), as are Vestispora tortuosa, V. spp. and Latensina. Stratigraphically unimportant taxa include Calamospora microrugosa, C. spp., Florinites mediapudens, Lycospora parva, L. subjuga, Laevigatosporites medius, $L$. desmoinesensis, Cyclogranisporites multigranus, Leiotriletes sphaerotriangulus and Raistrickia saetosa. Punctatisporites obesus makes up $\sim 30 \%$ of the assemblages and the monolete genus Laevigatosporites reaches $\sim 12 \%$.

\section{D4 SAMPLE}

Punctatisporites obesus is again the most abundant, comprising $23 \%$ of all specimens. Relatively abundant are the lycospores (Lycospora parva, L. brevijuga and L. spp.), vestispores (Vestispora tortuosa, V. spp.), Savitrisporites minor and Verrucosisporites microverrucosus. All other miospores are less common.

Long-ranging, i.e., stratigraphically unimportant taxa include the species Calamospora microrugosa, C. pedata, C liquida, Leiotriletes gulaferus, L. sphaerotriangulus, Florinites mediapudens, F. minutus, Laevigatosporites medius and Lophotriletes microsaetosus. Among species typical of this stratigraphical level, Dictyotriletes muricatus, Knoxisporites polygonalis, Vestispora tortuosa, Savitrisporites minor and Punctatisporites obesus were recognised.

\section{B3 SAMPLE}

The miospore assemblage of this sample was relatively poor compared to the samples above. The most abundant are vestispores (Vestispora tortuosa, V. pseudoreticulata and $V$. spp.), representatives of Leiotriletes and again Punctatisporites obesus. Other miospores were calamospores (Calamospora 


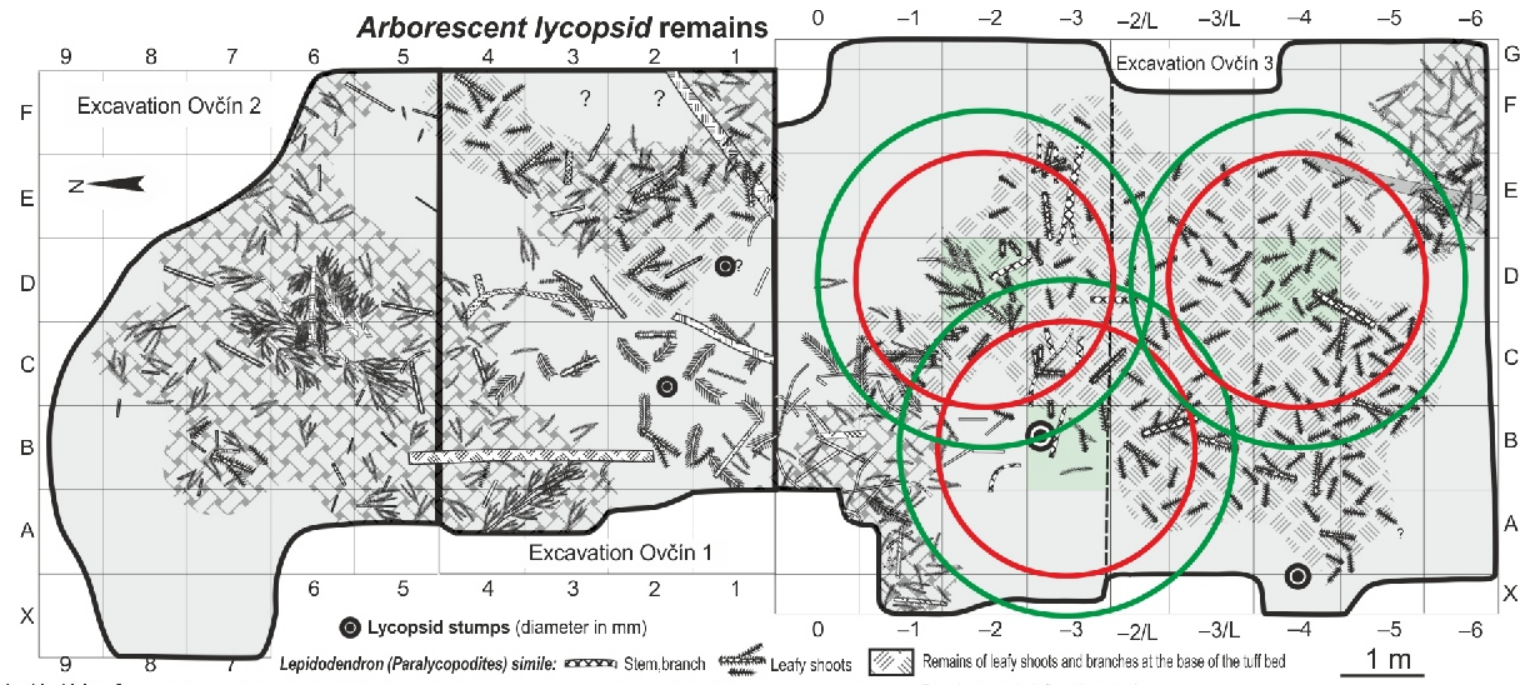

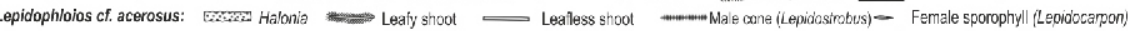

Lepidodendron lycopodioides: Stem branch $\geq$ Leafy shools - Cone isome of them atlached to leaty shoots) Remains of laafy shoots and branches at he jase of the tuf bed
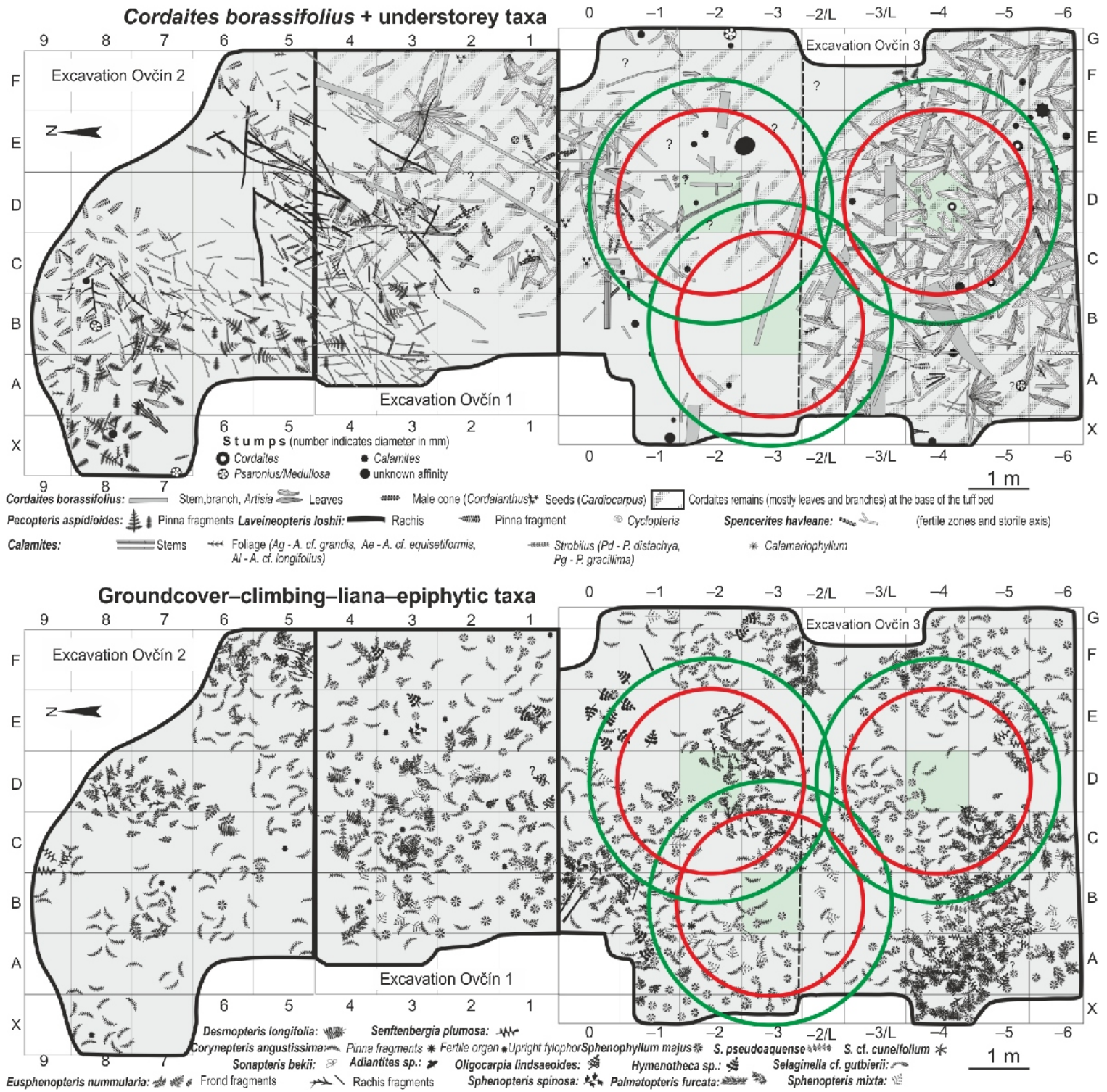

Fig. 3. Sternberg excavations (Sternberg 1, 2 and 3) in the Ovčín locality with indicated distribution of plant remains found in the Bělka tuff

Unidentifiable plant fragments and axes are omitted. The area excavated is shown in grey. Square units, which provided samples for palynological analyses are indicated in green. Green (4 $\mathrm{m}$ in diameter) and red (3 $\mathrm{m}$ in diameter) circles indicate areas where data on vegetation cover were calculated. Based on data in Opluštil et al. (2009) 
microrugosa and C. spp.), Lophotriletes microsaetosus, lycospores (Lycospora parva and L. spp.), Apiculatasporites spinulistratus. Knoxisporites polygonalis, Leiotriletes sphaerotriangulus and $L$. gulaferus.

Vestispores make up $\sim 22 \%$ of the assemblages, lycospores comprise $20 \%$ and Punctatisporites obesus reaches $25 \%$.

\section{COMPARATIVE SAMPLE}

It provides a good opportunity to demonstrate the use of R-values if we know the dispersed spore and pollen assemblage but not the plant record. The principle of the comparative sample is that it comes from identical stratigraphical level as those from the excavation, i.e., from the roof of the Lower Radnice Coal. The sample is from the VP-29 borehole situated $\sim 3 \mathrm{~km} \mathrm{SW}$ of the Ovčín opencast mine (Fig. 1). Using here-derived $\mathrm{R}$-values from excavations at Ovčín we attempted to estimate/calculate the percentage of aerial parts of plants in the very close proximity and estimate the composition of former vegetation in terms of the abundance of particular plant groups, to constrain lateral variations in the forest within one basin.

Miospores of three plant groups, the sphenophylls (21\%), arborescent lycopsids (27\%) and some ferns (26\%) are the most abundant and make about three-quarters of all specimens. Sphenophylls are represented by the species Laevigatosporites desmoinesensis, L. medius, Latosporites latus, Punctatisporites obesus, Vestispora pseudoreticulata, Reticulatasporites facetus and $R$. taciturnus. The cordaitealean pollen consisting of Florinites minutus. Lycospora brevis, L. subjuga, L. noctuina and Microspinosporites orbiculus are representatives of arborescent lycopsids of the genera Lepidodendron and/or Lepidophlois. Calamitean microspores can be compared to Calamospora microrugosa and C. pedata. Ferns produced the miospore species Leiotriletes adnatoides, Verrucosisporites microverrucosus, V. microtuberosus, Micro- reticulatisporites sulcatus, Granulatisporites minutus, G. gulaferus and G. microgranifer. We still do not know the parent plants for $13 \%$ of the miospores including Dictyotriletes castaneaeformis, Savitrisporites nux, Westphalensisporites irregularis and Ahrensisporites minutus.

\section{PARENT PLANTS}

The affinity of dispersed miospores and pollen is interpreted from in situ spores and pollen, i.e., spores and pollen isolated directly from the reproductive organs of fossil plants (Balme, 1995; Bek, 2017, 2021). Several new records of Pennsylvanian in situ spores and pollen from fertile specimens have been described from the Ovčín Mine (e.g., Bek et al., 2001, 2008; Drábková et al., 2004; Libertín and Bek, 2004; Libertín et al., 2014) that enable better intepretation of spore and pollen taxa in the basin. Generally it is possible to divide the dispersed miospore and pollen taxa described herein into several main categories according to their parent plants (Table 2). These main plant categories include lycopsids (arborescent, sub-arborescent and herbs), sphenopsids (calamites and sphenophylls), ferns (marattialeans, zygopterids, botryopterids, gleicheniaceans), cordaites, and spores and pollen of unknown affinity.

\section{B3 SAMPLE}

Miospores of sphenophylls (vestispores and Punctatisporites obesus) dominated and comprise $47 \%$ of all specimens. Miospores of arborescent lycopsids (lycospores) reach $\sim 23 \%$ and belong to the second the most abundant miospore group. Miospores of Leiotriletes (mainly gleicheniacean ferns) make up $\sim 13 \%$ of all specimens. Miospores of all other plants occur only in small numbers. Some calamites (Calamo-

Dispersed spores and pollen and their parent plants recorded at the locality

\begin{tabular}{|c|c|}
\hline Spores & Possible parent plants at the locality \\
\hline $\begin{array}{l}\text { Laevigatosporites medius, L. desmoinesensis, Latosporites saarensis } \\
\text { Vestispora tortuosa, V. sp. } \\
\text { Punctatisporites obesus } \\
\text { Dictyotriletes muricatus }\end{array}$ & $\begin{array}{c}\text { Sphenophylls: } \\
\text { Sphenophyllum majus } \\
\text { Sphenophyllum cf. cuneifolium } \\
\text { Bowmanites pseudoaquensis, } \\
\text { Bowmanites-Sphenophyllum sp. }\end{array}$ \\
\hline Lycospora parva, L. brevijuga. L. subjuga. L. spp. & $\begin{array}{c}\text { Arborescent lycopsids: } \\
\text { Lepidodendron lycopodioides, Lepidostrobus } \\
\text { obovatus, L. sternbergii }\end{array}$ \\
\hline $\begin{array}{l}\text { Spencerisporites spp. } \\
\text { Cirratriradites saturni }\end{array}$ & $\begin{array}{c}\text { Other lycopsids: } \\
\text { Spencerites havlenae, Selaginella gutbieri }\end{array}$ \\
\hline Calamospora microrugosa, C. pedata, C. liquida, C. spp. & $\begin{array}{c}\text { Calamites: } \\
\text { Palaeostachya gracillima, } P \text {. distachya }\end{array}$ \\
\hline Florinites mediapudens, F. minutus, F. spp. & $\begin{array}{c}\text { Cordaites: } \\
\text { Cordaites borassifolius, C. sp. }\end{array}$ \\
\hline $\begin{array}{l}\text { Raistrickia saetosa, } R \text {. spp. } \\
\text { Cyclogranisporites multigranus, C. minutus } \\
\text { Leiotriletes sphaerotriangulus, L. gulaferus, L. parvus, Lophotriletes microsaetosus } \\
\text { Verrucosisporites microverrucosus, V. spp. }\end{array}$ & $\begin{array}{c}\text { Ferns (marattialeans, zygopterids, botryopterids, } \\
\text { gleicheniaceans): } \\
\text { Senftenbergia plumosa } \\
\text { Pecopteris aspidioides, Sonapteris bekii } \\
\text { Oligocarpia lindsaeoides, Corynepteris } \\
\text { angustissima }\end{array}$ \\
\hline $\begin{array}{l}\text { Apiculatasporites spinulistratus } \\
\text { Acanthotriletes echinatus, Dictyotriletes spp. } \\
\text { Latensina triletus } \\
\text { Alatisporites pustulatus } \\
\text { Savitrisporites minor, S. nux } \\
\text { Knoxisporites polygonalis, K. spp. }\end{array}$ & Unknown origin \\
\hline
\end{tabular}


The main plant groups, percentage of their miospores in dispersed spore assemblages and R-values from B3, D2 and D4 samples

\begin{tabular}{|l|c|c|c|c|c|c|c|}
\hline \multirow{2}{*}{ Plant groups } & \multicolumn{2}{|c|}{ B3 } & \multicolumn{2}{c|}{ D2 } & \multicolumn{2}{c|}{ D4 } & Average \\
\cline { 2 - 9 } & $\begin{array}{c}\text { Miospores } \\
\text { and pollen [\%] }\end{array}$ & R-values & $\begin{array}{c}\text { Miospores } \\
\text { and pollen [\%] }\end{array}$ & R-values & $\begin{array}{c}\text { Miospores } \\
\text { and pollen [\%] }\end{array}$ & R-values & R-values \\
\hline Sphenophylls & 47 & 4.6 & 48 & 5 & 36 & 5.1 & 4.9 \\
\hline $\begin{array}{l}\text { Arborescent } \\
\text { lycopsids }\end{array}$ & 23 & 0.8 & 12 & 0.9 & 12 & 0.8 & 0.8 \\
\hline Other lycopsids & 0 & 0 & 7 & 23.3 & 2 & 40 & 31.6 \\
\hline Calamites & 7 & 23.3 & 8 & 1.8 & 7 & 3.7 & 9.6 \\
\hline Cordaites & 0 & 0 & 9 & 0.3 & 7 & 0.2 & 0.25 \\
\hline Ferns & 13 & 0.5 & 7 & 0.5 & 18 & 0.7 & 0.6 \\
\hline
\end{tabular}

spora-producing plants of genera like Calamostachys, Macrostachya and Palaeostachya and ferns of the Oligocarpia probably also grew in this area. The parent plants of other miospores, e.g., Apiculatasporites spinulistratus and Knoxisporites polygonalis, are still unknown.

\section{D2 SAMPLE}

Sphenophyllalean miospores make up $>50 \%$ of all specimens and sphenophylls probably were important contributors to biomass. Punctatisporites obesus makes up $30 \%$. All other miospores occur in relatively small numbers. Some sub-arborescent lycopsids of Spencerites type (Spencerisporites-producing), arborescent lycopsids of the genera Lepidophloios and/or Lepidodendron (Lycospora-producing), cordaites (Florinites-producing), Senftenbergia plumosa (Raistrickia-producing), Selaginella (Cirratriradites-producing), some calamites (Calamospora-producing) and ferns (Cyclogranisporitesproducing) probably also grew in that area. The parent plants of some miospores, such as Latensina, Knoxisporites and Alatisporites, are still unknown.

\section{D4 SAMPLE}

Sphenophyllalean miospores dominated again in this assemblage. Punctatisporites obesus, Laevigatosporites medius, Dictyotriletes muricatus and vestispores make up 36\% of the miospore assemblage and all of these were produced by different species of sphenophyll. Some representatives of arborescent lycopsids of the genera Lepidodendron and/or Lepidophloios that produced lycospores (Lycospora parva, L. brevijuga and L. spp.), cordaites (represented by Florinites) and some zygopterid ferns (produced genera Verrucosisporites, Leiotriletes and Lophotriletes) probably also grew at this locality.

The parent plants of Savitrisporites minor (relatively more abundant) and Acanthotriletes are still unknown.

\section{COMPARATIVE SAMPLE}

No macroplant record is known from around the VP-29 borehole. But we know their dispersed miospore and pollen assemblages and R-values from the Ovčín Mine. So we can estimate the general character of the flora in the same basin a few kilometres distant, through the principle of using R-values.

When we compare the general character of assemblage at the Ovčín Mine with that counted using R-values there are some differences. The most abundant plant group at the Ovčín Mine were cordaites, ferns were sub-dominant, and arborescent lycopsids were abundant but in the area of the VP-29 borehole ferns were dominant, arborescent lycopsids sub-dominant and cordaites were less common (Table 4). Calamites and other lycopsids were always rare and sphenophylls are twice as common at the Ovčín Mine. These differences can be explained by lateral changes within the basin including, for example, a different position/level in the swamp.

\section{THE R-VALUES/CONVERSION FACTORS}

We followed the principle of the R-values/conversion factors suggested by Willard (1993) and Willard and Phillips (1993). The percentage was counted for every miospore/pollen taxon of the main categories, i.e., arborescent lycopsids, other lycopsids, calamites, sphenophylls, ferns and cordaites (Ta-

T a ble 4

The main plant groups; percentages of their miospores in dispersed spore assemblages from the VP-29 borehole and Ovčín Mine

\begin{tabular}{|l|c|c|c|}
\hline \multirow{2}{*}{ Plant groups } & \multicolumn{2}{|c|}{ VP-29 } & Ovčín Mine \\
\cline { 2 - 4 } & $\begin{array}{c}\text { Miospores and } \\
\text { pollen [\%] }\end{array}$ & $\begin{array}{c}\text { Estimated percentage of aerial } \\
\text { parts of plants }\end{array}$ & $\begin{array}{c}\text { Average percentage of } \\
\text { aerial parts of plants }\end{array}$ \\
\hline Sphenophylls & 21 & 4.3 & 9 \\
\hline Arborescent lycopsids & 27 & 33.7 & 20 \\
\hline Other lycopsids & 2 & 0.06 & 0.2 \\
\hline Calamites & 9 & 0.9 & 0.8 \\
\hline Cordaites & 2 & 8 & 40 \\
\hline Ferns & 26 & 43.3 & 30 \\
\hline
\end{tabular}


ble 3) for each circle (B3, D2 and D4). The same was done for aerial parts of their parent plants.

This means that the percentages of some plant groups do not represent the number of plant specimens but the percentages of aerial parts of plants that covered the surface. R-values/conversion factors have been counted based on the formula proposed by Willard (1993) and Willard and Phillips (1993). Pteridosperm pollen are not represented in the palynological record although their parent plants occur in the area of all three samples. This may have resulted from their size (e.g. Schopfipollenites type) and low production because they usually do not occur in palynological slides (maceration, sieving).

Miospores of arborescent lycopsids (the genus Lycospora) are 0.8 times under-represented; miospores of other lycopsids (sub-arborescent and herbs) are surprisingly 31 times over-represented, the calamitean miospores (the genus Calamospora) are almost ten times (9.6) over-represented and sphenophyllalean miospores are also almost five times (4.9) over-represented. The miospores of ferns are 0.6 times under-represented and the pollen of cordaites (the genus Florinites) are 0.25 times under-represented.

\section{DISCUSSION}

R-values can help with better interpretation of vegetation based on the miospore/pollen record than the direct but simplified "translation" that the percentage of spores is more or less equal to the abundance of their parent plants.

The quantitative relationship between spores and their parent plants is influenced by several factors. One of these may be the height of plants, which can affect the dispersal of miospores. Thus the spores/pollen of arborescent plants (e.g., lycopsids) with a canopy above the dense groundcover were probably more evenly distributed by wind across a large area with relatively few of them falling close to a parent tree.

In contrast, most miospores produced by lower sub-arborescent and herbaceous forms fall closer to their producers resulting in patchy abundance of their spores/pollen that follows the distribution of their parent plants. This effect is further combined with differences in production of spores/pollen by different plant taxa. Arborescent lycopsids produced cones ten of centimetres to almost one metre long (Bek and Opluštil, 2004; Opluštil et al., 2009, 2014) whereas selaginellas, small herbs with thin axes, bore small cones a few centimetres long. Another group of lycopsids, sub-arborescent forms (2-4 m high) have numbers of sporangia arranged in fertile zones on the stem. For example, arborescent and sub-arborescent lycopsids produced enormous numbers of miospores compared to selaginellas. The reproductive strategies of plants are also a factor, which varied substantially from continuous or repeated reproduction (typically ferns and some lycopsids, e.g., Paralycopodites, Omphalophloios, herbaceous lycopsids) to massive reproduction at the end of life cycle as in the case of some arborescent lycopsids Lepidodendron and Lepidophloios with determinate growth (DiMichele and Phillips, 1994 DiMichele, 2014). The latter, however, may have been balanced by the co-occurence of plants at various stages of their life cycle, some of them being in the reproductive stage. These taphonomic biases affected the proportions between miospores and macrofloral records as regards their abundances.

Another feature is that miospores borne in cones $30-40 \mathrm{~m}$ above the surface were probably dispersed extensively with only a minority of them falling close to a parent tree. The majority of miospores produced by lower sub-arborescent and herba- ceous forms fall closer to their parent plants and probably only a minority of them were dispersed over longer distances.

However, the ratio of biomass to spores should remain more or less the same when comparing different localities, as the forest included individual plants at different stages of maturity of arborescent forms.

This disproportion is consistent with different R-values of arborescent $(0.8$, i.e., slightly under-represented) and other lycopsids (31.6, i.e., strongly over-represented).

Sphenopsids are divided into calamitean trees and sphenophylls. Calamitean trunks were 10-15 m high but sphenophylls had a more herbaceous character often with smaller cones, some comparable in size with those of some selaginellas. An assumed higher production of calamite spores is probably the reason why the R-value of calamites (10) is twice as high as that of sphenophylls (5), i.e., miospores of sphenophytes are generally over-represented in the dispersed record.

There are different R-values for fern spores and cordaitalean pollen (Florinites type). The height of cordaitalean trees was comparable to that of arborescent lycopsids and the area covered by remains of both plant groups in the excavation was also similar (Fig. 3 and Table 3). However, representatives of these two plant groups had different reproductive strategies. Seeds of cordaites are recorded rarely but the production of their pollen was much higher, probably comparable to that of arborescent lycopsids. The morphology of cordaitalean pollen, i.e., their saccate character, is more suitable for wind dispersal than water transport. This means that the amount of pollen falling close to the position of their parent plants must have been several times smaller than the amount of pollen produced by much smaller/lower plants. Pollen from 20-30 m high cordaitaleans were transported by the wind over a huge area and probably only a minority fell close to the trunk, i.e., a similar effect as in arborescent lycopsids but amplified by the presence of pollen sacs. This is probably why cordaitalean pollen were strongly under-represented ( 0.25 times).

The situation with fern spores is more complicated because the habit of their parent plants is variable including small herb-like taxa, lianas and arborescent marattialean forms. Probably, the R-values of each fern group were different. Spores of ferns were not born in cones or fertile zones but in sporangia/synangia grouped on fertile fronds in a relatively limited number. Based on the size and the number of fern sporangia, the production of fern spores was probably several times smaller (from a quantitative view) than than for the previously discussed main plant groups. This is probably the reason why fern miospores are under-represented ( $R$-value is 0.6$)$.

"Coal-balls" and "adpression" R-values of arborescent lycopsids are roughly comparable i.e., 1. Willard's (1993) $\mathrm{R}$-value means that these miospores are slightly over-represented (1.1) and the R-values given heein mean that they are slightly under-represented (0.8). Sphenopsid miospores are over-represented in both types of preservation, Adpression sphenopsid miospores have higher R-values (7.3) than those from coal-balls (3.1). Ferns have quite different R-values, suggesting that those from adpressions in the Ovčín excavations are under-represented (0.6) but from coal-bals are almost four times (3.8) over-represented. This might be because Willard (1993) derived her R-values from the Desmoinesian ( Asturian in Europe) Springfield Coal, formed at a time when tree ferns predominated in peat swamp habitats (Phillips et al., 1985; DiMichele and Phillips, 1994). By contrast, the Lower Radnice Coal is of late Duckmantian age when arborescent lycopsids were dominant peat-forming plants. A similar situation concerns cordaitalean pollen. Dispersed Florinites is under-repre- 
sented $(0.25)$ in the adpression record but over-represented (1.5) in coal-balls.

It is possible to explain some differences in R-values of both modes of preservation by different plant species having different reproductive strategies, different palaeoenvironments, edaphic factors, nutrient supply and changes in vegetation patterns throughout the Pennsylvanian. If we compare routine "translation" of the percentage of miospores/pollen into the same percentage of their parent plants following the concept of $\mathrm{R}$-values there are some important corrections. The percentage of miospores of arborescent lycopsids and that of their parent plants seems more or less equal. A different situation concerns the miospores of other lycopsids, that are strongly over-represented, i.e., the percentage of their parent plants was significanty smaller than that of their spores. The percentages of sphenophylls and calamites as macroplants were smaller than those of their spores, i.e., the parent plants are under-represented. It is necessary to increase the estimate of the percentage of ferns and cordaites in comparison to the percentage of their miospores and pollen because these spores and pollen are under-represented.

Our results are of a preliminary character because maceration of samples from the Ovčín Mine excavation and related research is in progress.

\section{CONCLUSIONS}

Preliminary conclusions can be made based on comparison of quantified palynological and macrofloral adpression records from only three samples and many such comparisons will be necessary to test the conclusions suggested below:

1. Spores of arborescent lycopsids are slightly under-represented (R-value is 0.8), i.e., slightly under-represented) and those of other lycopsids are strongly over-represented (R-value is 31.6).

2. Calamitalean spores are over-represented two-fold ( $R$-value is 10 ) than sphenophyllalean spores (R-value is 5), i.e., miospores of sphenophytes are generally over-represented in the dispersed record.

3. Cordaitalean pollen are strongly under-represented (R-values is 0.25).

4. Fern spores are under-represented (R-value is 0.6).

5. "Coal-ball" and "adpression" R-values of arborescent lycopsids are roughly comparable i.e., $\sim 1$.

6. Sphenopsid miospores are over-represented in both types of preservation. Adpression sphenopsid miospores (7.3) have higher R-values than those from coal-balls (3.1).

7. Fern spores from both modes of preservation have quite different R-values because those from adpressions are under-represented (0.6) and from coal-balls are almost four times (3.8) over-represented.

8. Cordaitalean pollen are under-represented $(0.25)$ in the adpression record but over-represented (1.5) in coal-balls.
Acknowledgements. This paper was partly prepared with the financial support of the Grant Agency of the Czech Republic (project no. 19-06728S) and the research plan of the Institute of Geology of the Czech Academy of Sciences, v.v.i., RVO67985831. We are obliged to J. E. Marshall (University of Southampton, UK) for corrections of the English. The reviewers C. Cleal (University of Bristol, UK), P. Filipiak (University of Silesia, Sosnowiec, Poland) and Grzegorz Pacyna (Jagellonian University, Kraków, Poland) are thanked for helpful remarks and suggestions.

List of miospores and pollen from B3, D2 and D4 samples from the Ovčín Mine:

Acanthotriletes echinatus (Knox) Potonié and Kremp

Alatisporites pustulatus Ibrahim

Apiculatasporites spinulistratus (Loose) Ibrahim

Calamospora liquida Kosanke

Calamospora microrugosa (Ibrahim) Schopf, Wilson and

Bentall

Calamospora pedata Kosanke

Calamospora spp.

Cirratriradites saturni (Ibrahim) Schopf, Wilson and Betall

Cyclogranisporites minutus Bharadwaj

Cyclogranisporites multigranus Smith and Butterworth

Dictyotriletes muricatus (Kosanke) Smith and Butterworth

Dictyotriletes spp.

Florinites mediapudens (Loose) Potonié and Kremp

Florinites minutus Bharadwaj

Florinites spp.

Knoxisporites polygonalis (Ibrahim) Potonié \& Kremp

Knoxisporites spp.

Laevigatosporites desmoinesensis (Wilson and Coe) Schopf,

Wilson and Bental

Laevigatosporites medius Kosanke

Latosporites saarensis Bharadwaj

Latensina triletus Bharadwaj

Leiotriletes gulaferus Potonié and Kremp.

Leiotriletes parvus Guennel

Leiotriletes sphaerotriangulus (Loose) Potonié and Kremp

Lophotriletes microsaetosus (Loose) Potonié and Kremp

Lycospora brevijuga Kosanke

Lycospora parva Kosanke

Lycospora spp.

Lycospora subjuga Bharadwaj

Punctatisporites obesus /Loose) Potonié and Kremp

Raistrickia saetosa (Loose) Schopf, Wilson and Bentall

Raistrickia spp.

Savitrisporites minor Jachowicz

Savitrisporites nux (Butterworth and Williams) Smith and Butterworth

Spencerisporites spp.

Verrucosisporites microverrucosus Ibrahim

Verrucosisporites spp.

Vestispora pseudoreticulata Spode

Vestispora spp.

Vestispora tortuosa (Balme) Bharadwaj 


\section{REFERENCES}

Balme, B.A., 1995. Fossil in situ spores and pollen grains: an annotated catalogue. Review of Palaeobotany and Palynology, 87 81-323.

Bateman, R.M., Hilton, J., 2009. Palaeobotanical systematics for the phylogenetic age: applying organ-species, form-species and phylogenetic species concepts in a framework of reconstructed fossil and extant whole-plants. Taxon, 58: 1254-1280.

Bek, J., 1986. Palynologická charakteristika vrtu VP-29 z lokality Přivětice-Ovčín (in Czech). MSc. thesis, Faculty of Sciences, Charles University, Prague.

Bek, J., 2017. Paleozoic in situ spores and pollen. Lycopsida, Palaeontographica Abteilung B, 296: 1-111.

Bek, J., 2021. Paleozoic in situ spores and pollen. Sphenopsida, Palaeontographica Abteilung B, 301: 141-201.

Bek, J., Opluštil, S., 2004. Palaeoecological constraints of some Lepidostrobus cones and their parent plants from the Late Palaeozoic continental basins of the Czech Republic. Review of Palaeobotany and Palynology, 131: 49-89.

Bek, J., Opluštil, S., 2021. Early Pennsylvanian to early Permian (Bashkirian-Asselian) miospore and pollen assemblages of the Czech part of the Intra-Sudetic Basin. Bulletin of Geosciences, 96: 341-379.

Bek, J., Opluštil, S., Drábková, J., 2001. Two species of of Selaginella cones and their spores from the Bohemian Carboniferous continental basins of the Czech Republic. Review of Palaeobotany and Palynology, 114: 57-81.

Bek, J., Drábková, J., Dašková, J., Libertín, M., 2008. The sub-arborescent lycopsid genus Polysporia Newberry and its spores from the Pennsylvanian (Bolsovian-Stephanian B) continental basins of the Czech Republic. Review of Palaeobotany and Palynology, 152: 176-199.

Burnham, R.J., 1994. Plant deposition in modern volcanic environments. Transactions of the Royal Society of Edinburgh, Earth Sciences, 84: 275-281.

Burnham, R.J., Spicer, R.A., 1986. Forest litter preserved by volcanic activity at El Chicon, Mexico: a potentially accurate record of the pre-eruption vegetation. Palaios, 1: 158-161.

Capel, E., Cleal, C.J., Gerrienne, P., Servais, T., Cascales-Minana, B., 2021. A factor analysis approach to modelling the early diversification of terrestrial vegetation. Palaeogeography, Palaeoclimatology, Palaeoecology, 566: 110-170.

Davis, M.B., 1963. On the theory of pollen analysis: American Journal of Science, 261: 897-912

DiMichele, W.A., 2014. Wetland-dryland vegetational dynamics in the Pennsylvanian ice age tropics. International Journal of Plant Science, 175: 123-164.

DiMichele, W.A., Phillips, T.L., 1994. Paleobotanical and paleoecological constraints on models of peat formation in the Late Carboniferous of Euramerica. Palaeogeography, Palaeoclimatology, Palaeoecology, 106: 39-90.

Drábková, J., 1986. Litologická a palynologická charakteristika karbonských sedimentů na Dole Pokrok - Přívětice (in Czech). Msc. thesis, Faculty of Sciences, Charles University, Prague.

Drábková, J., Bek, J., Opluštil, S., 2004. The first compression fossils of Spencerites (Scott) emend., and its isospores, from the Bolsovian (Pennsylvanian) of the Kladno-Rakovník and Radnice basins, Czech Republic. Review of Palaeobotany and Palynology, 130: 59-88.

Kalibová-Kaiserová, M., 1959. Rod Valvisisporites (Ibrahim 1933) Pot. et Kr. 1954 (Triletes auritus Zerndt, typ II Zerndt) a jeho druhy včekém permokarbonu (in Czech). Věstník Ústředného ústavu geologického, 34: 429-436.

Libertín, M., Bek, J., 2004. Huttonia spicata (Sternberg) emend. and its spores, the Radnice Basin (Bolsovian), Carboniferous continental basins of the Czech Republic. Review of Palaeobotany and Palynology, 128: 247-261.

Libertín, M., Bek, J., Drábková, J., 2014. New sphenophyllaleans from the Pennsylvanian of the Czech Republic. Review of Palaeobotany and Palynology, 200: 196-210.
Němejc, F., 1930. Floristické poznámky ku stratigrafii některých uhelných pánviček mezi Rokycany a Berounem (in Czech). Věstník státního geologického ústavu Československé Republiky, 6: 40-58.

Opluštil, S., 2010. Contribution to knowledge on ontogenetic developmental stages of Lepidodendron mannebachense Presl 1838. Bulletin of Geosciences, 85: 303-316.

Opluštil, S., Pšenička, J., Libertín, M., Šimůnek, Z., 2007. Vegetation patterns of Westphalian and Lower Stephanian mire assemblages preserved in tuff beds of the continental basins of Czech Republic. Review of Palaeobotany and Palynology, 143: 107-154.

Opluštil, S., Pšenička, J., Libertín, M., Bashforth, A.R., Šimůnek, Z., Drábková, J., Dašková, J., 2009. Composition and structure of an in situ Middle Pennsylvanian peat-forming plant assemblage buried in volcanic ash, Radnice Basin (Czech Republic). Palaios, 24: 726-746.

Opluštil, S., Pšenička, J., Bek, J., Wang, J., Feng, Z., Libertín, M., Šimùnek, Z., Bureš, J., Drábková, J., 2014. T0 peat-forming plant assemblage preserved in growth position by volcanic ash-fall: a case study from the Middle Pennsylvanian of the Czech Republic. Bulletin of Geosciences, 89: 773-818.

Opluštil, S., Schmidt, M., Cleal, C. J., Martínek, K., 2016. A review of the Middle-Late Pennsylvanian west European regional substages and floral biozones, and their correlation to the Geological Time Scale based on new U-Pb ages. Earth-Science Reviews, 154: 301-335.

Opluštil, S., Wang, J., Pfefferkorn, H.W., Pšenička, J., Bek, J., Libertín, M., Wang, J., Wan, M., He, X., Menxiao, Y., Wei, H., Votočková-Frojdová, J., 2021. T0 Early Permian coal-forest preserved in situ in volcanic ash bed in the Wuda Coalfield, Inner Mongolia, China. Review of Palaeobotany and Palynology, 294, 104347.

Orlov, A., 1942. Sedimenty uhelných slojí v kladenské černouhelné pánvi (in Czech). Zprávy Geologického ústavu Čechy a Morava, 17: 221-253.

Pešek, J., Holub, v., Jaroš, J., Malý, L., Martínek, K., Prouza, V., Spudil, J., Tásler, R., 2001. Geologie a ložiska svrchnopaleozoických limnických pánví České republiky (in Czech). Český geologický ústav, Praha.

Pfefferkorn, H.W., Wang, J., 2007. Early Permian coal-forming floras preserved as compressions from the Wuda District (Inner Mongolia, China). International Journal of Coal Geology, 69: 90-102.

Phillips, T.L., Peppers, R.A., DiMichele, W.A., 1985. Stratigraphic and interregional changes in Pennsylvanian coal swamp vegetation: environmental inferences. International Journal of Coal Geology 5: 43-109.

Potonié, R., Kremp, G., 1954. Die Gattungen der Palaözoischen Sporae dispersae und ihre Stratigraphie. Geologische Jahrbuch, 69: 111-193.

Potonié, R., Kremp, G., 1955. Die Sporae dispersae des Ruhrkarbons ihre Morphographie und Stratigraphie mit Ausblicken auf Arten anderer Gebiete und Zeitabschnitte. Teil I. Palaeontographica Abteilung B, 98: 1-136.

Pšenička, J., Opluštil, S., 2013. The epiphytic plants in the fossil record and its example from in situ tuff from Pennsylvanian of Radnice Basin (Czech Republic). Bulletin of Geosciences 88: 401-416.

Pšenička, J., Schultka, S., 2009. Revision of the Carboniferous genus Rhodeites Němejc from European and American localities. Bulletin of Geosciences, 84: 241-256.

Punt, W., Hoen, P.P., Blackmore, S., Nilsson, S., Le Thomas, A., 2007. Glossary of pollen and spore terminology. Review of Palaeobotany and Palynology, 143: 1-81.

Smith, A.H.V., Butterworth, M.A., 1967. Miospores in the coal seams of the Carboniferous of Great Britain. Special Papers in Palaeontology, 1: 1-324. 
Sternberg, G.K., 1820-1838. Versuch einer geognostisehen botanisehen Darstellung der Flora der Vorwelt, 1 (1): 1-24, 1820; 1 (2): 1-33, 1822; 1 (3): 1-39,1823; 1 (4): 1-48, 1825a; 2 (5-6): 1-80,1833; 2 (7-8): 1838.

Šimůnek, Z., Opluštil, S., Drábková, J., 2009. Cordaites borassifolius (Sternberg) Unger (Cordaitales) from the Radnice Basin (Bolsovian, Czech Republic). Bulletin of Geosciences, 84: 301-336.

Tomek. F., Opluštil, S., Svojtka, M., Špillar, V., Rapprich, V., Míková, J., 2021. Altenberg-Teplice Caldera sourced Westphalian fall tuffs in the central and western Bohemian Carboniferous basins (eastern Variscan belt). International Geology Review, 4, 1-29.

Wang, J., Pfefferkorn, H. W., Bek, J., 2009. Paratingia wudensis sp. nov., a whole noeggerathialean plant preserved in an earliest Permian air fall tuff in Inner Mongolia, China. American Journal of Botany, 96: 1676-1689.

Wang, J., Pfefferkorn, H.W., Zhang, Y., Feng, Z., 2012. Permian vegetational Pompeii from Inner Mongolia and its implications for landscape paleoecology and paleobiogegraphy of Cathaysia. Proceedings of the National Academy of Sciences, 109: 4927-4932.

Wang, J., Wan, S., Kerp, H., Bek, J., Wang, S., 2021. A whole noeggerathialean plant Tingia unita Wang from the earliest Permian peat-forming flora, Wuda Coalfield, Inner Mongolia. Review of Palaeobotany and Palynology, 294, 104204.

Willard, D.A., 1993. Vegetational patterns in the Springfield Coal (Middle Pennsylvanian, Illinois Basin): Comparison of miospore and coal-ball records. GSA Special Paper, 286: 139-152.

Willard, D.A., Phillips, T. L., 1993. Paleobotany and palynology of the Bristol Hill Coal Member (Bond Formation) and Friendsville Coal Member (Mattoon Formation) of the Illinois Basin (Upper Pennsylvanian). Palaios, 8: 574-586.

Zhou, W., Pšenička, J., Bek, J., Wan, J., Boyce, K., Wang, J., 2021. A new anachoropterid fern from the Asselian (Cisuralian) Wuda tuff flora. Review of Palaeobotany and Palynology, 294, 104346. 